\title{
Evaluation of Onion Genotypes for Growth and Bulb Yield in Mid Hill of Nepal
}

Ishwori Prasad Gautam ${ }^{1 *}$, Navin Gopal Pradhan ${ }^{1}$, Binod Prasad Luitel ${ }^{2}$ and Sujan Subedi ${ }^{1}$

${ }^{1}$ Horticulture Research Division, NARC, Khumaltar, Lalitpur, Nepal. @: ishworigautam@gmail.com, ORCID: https://orcid.org/0000-0003-0682-9306; NGP: navin.pradhan@ gmail.com,

SS: suzsubedi@gmail.com

${ }^{2}$ Horticulture Research Station, Kimugaun, Dailekh; binodsan@yahoo.com

Received 13 Sept 2018, Revised 25 Jan 2019, Accepted 27 Jan 2019, Published 28 April 2019

Scientific Editors: Umesh Acharya, Jiban Shrestha

Copyright $@ 2019$ NARC. Permits unrestricted use, distribution and reproduction in any medium provided the original work is properly cited.

The authors declare that there is no conflict of interest.

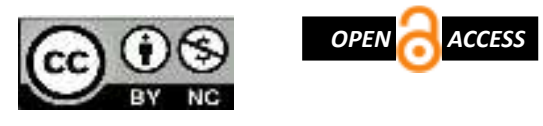

Licensed under the Creative Commons AttributionNonCommercial 4.0 International (CC BY-NC 4.0)

\begin{abstract}
Experiments were conducted at Horticulture Research Division (HRD), Khumaltar, Lalitpur; and Horticulture Research Station (HRS), Kimugaun, Dailekh in 2017/18 to evaluate the high yielding open pollinated genotypes of onion in mid hills of both locations. Five onion genotypes namely AVON-1016, AVON-1027, AVON-1028, AVON-1052, AVON-1074 and AVON-1103 received from Asian Vegetable Research and Development Centre were evaluated with local check variety and recommended variety Red Creole in both locations in randomized complete block design with 4 replications. The main objective of the experiment is to findout the high yielding open pollinated onion genotypes for mid hill condition. The pooled analysis of data over locations showed significant differences on plant height, neck diameter, bulb diameter, weight of bulbs and adjusted bulb yield per hectare. Introduced genotypes AVON 1027 (38.83 t/ha), AVON 1052 (31.97 t/ha) and AVON 1028 (31.48 t/ha) produced significantly higher yield than recommended and commercially cultivated check variety Red Creole (27.04 t/ha). Therefore the genotype AVON 1027 can be selected as the best genotype for growing in mid hills of Nepal
\end{abstract}

Keywords: Allium, bulb size, bulb shape, bulb diameter, yield

\section{सारांश}

वागवानी अनुसन्धान महाशाखा, खमलटार, ललितपुर र वागवानी अनुसन्धान केन्द्र, किमगाउँ, दैलेखमा आ.ब. २०१७/१६ मा एशियन तरकारी अनुसन्धान तथा विकास केन्द्रबाट ल्याइएका प्याजका ६ वटा जातहरु ए.भि.ओ.एन. १०१६, ए.भि.ओ.एन. १०२७, ए.भि.ओ.एन. १०२६, ए.भि.ओ.एन. १०४२२ र ए.भि.ओ.एन. १९०३ को नेपालमा लगाउन सिफारिस जात रेड क्रियोलसँग तुलना गरिएको थियो। उक्त जातहरुको दुवै ठाउँको उत्पादन र अन्य गुण विश्लेषण गर्दा बाहिरबाट ल्याइएका जातहरु ए.भि.ओ.एन. १०२७ (३६.८३ टन/हे.), ए.भि.ओ.एन. १०४२ (३१.९७ टन/हे.) र ए.भि.ओ.एन. १०२६ (३१.४६ टन/हे.) नेपालमा लगाउन सिफारिस रेड क्रियोल (२७. ४० टन/हे.) ले भन्दा बढी उत्पादन दिएकोले प्रवर्द्धन गर्न सकिने देखियो।

\section{INTRODUCTION}

Onion (Allium cepa L.) is one of the most important vegetable crop grown in the world. As a food items, it is usually served as cooked vegetable or a part of prepared savory dishes but can also be eaten raw or used to make pickles or chutneys. A global review of area and production of major vegetable crops shows that the onion ranks third in area and production (IHD 2014). Onion is one of the important condiments widely used in all households all the year round in Nepal. It is rich source of phosphorus, calcium and carbohydrate. Besides these the antibacterial and anti-fungal properties, it has been used to prevent infection in wound and burn for centuries. It is thought that onion and other Allium family have some impact on reduction of high cholesterol and blood pressure. One amusing bit of folklore says that if you put onion juice on your head, and then sit out in the sun, you can cure the baldness.

The area, production and productivity of onion in Nepal is 20,070 ha, 2,38,590.7 $\mathrm{t}$ and $11.9 \mathrm{t} / \mathrm{ha}$, respectively (VDD 2072/73). This production fulfilled around $41.15 \%$ of national demand and 
remaining $58.85 \%$ demand is fulfilled by importing fresh or chilled and dry onion from other countries. In fiscal year 2016/17, Nepal imported 1,23,345.52 tons fresh/ chilled onion from different countries with total value of NRs 3,983.08 million (3.98 Arab). Similarly, the total amount of dry onion imported from India, China, Nicaragua and Thailand was 7,067.75 tons with total worth of NRs 235.81 million (NFTS 2016/17). Based on the domestic production and import, the per capita consumption of onion in fiscal year $2018 / 19$ is $12.86 \mathrm{~kg}$ which is lower than the average annual consumption $30.7 \mathrm{~kg}$ per person across the world. Libya has the highest per capita consumption of onion $146.96 \mathrm{~kg}$ around the world (http://bit.ly/2sOEIKo).

The low productivity of onion in Nepal than world average and neighboring countries is governed by many factors like low yielding and limited number of varieties, unavailability of quality seed at required planting time and place, pre-mature bolting, bulb splitting, poor adaptation of cultivars to low input management conditions etc. Most of the imported cultivars available in the market are hybrids and high inputs responsive so farmers cannot afford high price for seed every year and high inputs cost. Furthermore, there is unavailable of hybrids varieties in markets which have been registered in the past. So farmers have not access of these varieties. Thus, most of the farmers are using only one or two recommended and registered open pollinated variety for bulbs production and their own saved seed for production. Introduction, testing and selection of new high yielding open pollinates varieties is the best option for increasing the yield and productivity. It is reported by Asian Vegetable Research and Development Centre that there are some new genotypes that have yield potentiality of more than $45 \mathrm{t} / \mathrm{ha}$ (http://bit.ly/2MyepBg). If these new open pollinated (OP) varieties perform best in our locations, there will be increase in yield and productivity. Furthermore, farmers can produce their own seed for future production with reduced costs using such OP varieties. Considering this, Nepal Seed and Fertilizer (NSAF) project included this crop for his program and support horticulture research division for development of new open pollinated varieties, whose seeds can be produced with in the country for sustainable production

\section{MATERIAL AND METHODS}

\section{Experimental site}

Experiment was conducted concurrently at Horticulture Research Division (HRD), Khumaltar and Horticulture Research Station (HRS), Dailekh during the year 2017/18 to find out the high yielding genotypes of onion.

\section{Experimental materials, design and Cultural practices}

The seeds of six onion genotypes viz. AVON-1016, AVON-1027, AVON-1028, AVON-1052, AVON 1074 and AVON-1103 were obtained from Nepal Seed and Fertilizer project (NSAF) which were received from Asian Vegetable Research and Development Centre (AVRDC), Taiwan.

Among these genotypes AVON 1074 was not germinated in both locations. Remaining five genotypes along with Red Creole as check variety were tested in both locations.

a) At HRD Khumaltar: At HRD Khumaltar, the trial was laid out in Randomized Complete Block Design (RCPD) with four replications. Seeds were sown in nursery bed on $1^{\text {st }}$ November and germinated on $11^{\text {th }}$ November, 2017. The 57 days old seedlings were transplanted on $28^{\text {th }}$ December, 2017 at a spacing of $20 \times 15 \mathrm{~cm}$. The plot size was maintained $2 \mathrm{~m}^{2}$ (5 rows with $2 \mathrm{~m}$ long). Manure and fertilizers were applied at the rate of 20 ton FYM plus 100:80:60 kg N, $\mathrm{P}_{2} \mathrm{O}_{5}$ and $\mathrm{K}_{2} \mathrm{O} / \mathrm{ha}$. FYM, full dose of phosphorus, potash and half dose of nitrogen were applied at the final land preparation and remaining half dose of nitrogen was applied as topdressing in two equal doses at 20 and 60 days after transplanting. Protective spray of fungicides Diathane M-45 and Kerasil against powdery mildew and pruple blotch diseases were carried out on $30^{\text {th }}$ March and $22^{\text {nd }}$ April, 2018 respectively.

b) At HRS, Dailekh: At HRS, Dailekh, the trial was laid out in Randomized Block Design with four replications. The nursery was placed on $28^{\text {th }}$ October, 2017 and 63 days old seedlings were transplanted on $29^{\text {th }}$ December, 2017. A total of 30 seedlings of six genotypes were transplanted in two-meter square plot with a spacing of $20 \mathrm{~cm} \times 15 \mathrm{~cm}$. The fertilizer was used at a rate of 100:80:60 
$\mathrm{kg} \mathrm{N}, \mathrm{P}_{2} \mathrm{O}_{5}: \mathrm{K}_{2} \mathrm{O}$ along with 20 ton FYM per hectare, respectively, which was recommended for onion by Chalise and Pun (2012). As a general practice, full doses of phosphorous and potassium, half doses of nitrogen and FYM were applied at the time of land preparation while half dose of nitrogen was split top dressed equally at 25 and 50 days after transplanting.

\section{Data collection and analysis}

Observations on plant morphological characters such as plant height, neck and bulb diameter, bulb weight, total bulb weight/plot and total bulb yield were recorded in both locations. The qualitative characters like neck and bulb color were also observed. The crop was harvested at 140 days after transplanting on $17^{\text {th }}$ May, in HRD, Khumaltar and 151 days after transplanting on $29^{\text {th }}$ May, 2018 at HRS, Dailekh. For general information like leaf length and neck diameter at different intervols, leaf height and foliage colour and foliage cracking at maturity, bubl uniformity were also recorded at HRD, Khumaltar. The observed data were adjusted and analyzed using GenStat 5, Release 3.2 (1995).

\section{RESULTS}

\section{Leaf Length and Numbers}

The combined analysis showed non-significant differences on leaf length due to genotypes and location, and interaction of genotypes and location. However, leaf length differed significantly in HRS, Dailekh. The longest leaf length $(41.63 \mathrm{~cm})$ was recorded in genotype AVON-1027 followed by variety Red Creole $(39.48 \mathrm{~cm})$ and they were statistically at par with genotype Red Creole and it was statistically at par with genotype AVON- $1027(40.53 \mathrm{~cm})$ and the shortest leaf length $(30.10 \mathrm{~cm})$ was recorded in genotype AVON-1052. The detail leaf length in each location and their combined effect on leaf length is presented in Table 1.

Table 1. Effect of onion genotypes on length and number of leaves in mid hills of Nepal, 2017/18

\begin{tabular}{|c|c|c|c|c|c|c|}
\hline \multirow[t]{2}{*}{ Genotype } & \multicolumn{3}{|c|}{ Leaf length $(\mathrm{cm})$} & \multicolumn{3}{|c|}{ Number of leaves } \\
\hline & Dailekh & Khumaltar & Mean & Dailekh & Khumaltar & Mean \\
\hline AVON-1016 & $35.37 a b$ & 34.0 & 36.49 & 9.13 & $10.13 a b c$ & 9.63 \\
\hline AVON-1027 & $40.53 a$ & 36.4 & 38.48 & 9.37 & $10.40 a b$ & 9.88 \\
\hline AVON-1028 & $35.30 a b$ & 37.7 & 36.50 & 8.33 & $9.27 c$ & 8.80 \\
\hline AVON-1052 & $30.10 b$ & 38.3 & 34.20 & 8.33 & $9.27 c$ & 8.80 \\
\hline AVON-1103 & $37.17 a b$ & 36.5 & 36.86 & 8.77 & $9.50 b c$ & 9.13 \\
\hline Red Creole & $41.63 a$ & 37.7 & 39.67 & 9.80 & $10.50 a$ & 10.15 \\
\hline Mean & 37.09 & 36.8 & 36.73 & 8.95 & 9.84 & 9.40 \\
\hline \multicolumn{7}{|l|}{ F-test } \\
\hline Genotypes & $*$ & NS & NS & NS & $*$ & $* * *$ \\
\hline Locations & - & NS & NS & - & - & $* *$ \\
\hline Geno. $\times$ Loc. & NS & NS & NS & - & - & NS \\
\hline LSD (0.05) & & & NS & & - & \\
\hline Genotypes & 6.81 & - & - & - & 0.923 & 0.76 \\
\hline Locations & - & & & - & - & 0.43 \\
\hline Geno. $\times$ Loc. & & & & - & - & - \\
\hline $\mathrm{CV} \%$ & 10.2 & 11.6 & 10.6 & 8.8 & 5.2 & 6.8 \\
\hline
\end{tabular}

NS = Non Significant; , *,** and *** Significant at 0.05, 0.01 and <0.001 levels respectively. In column figures with same small letter $(s)$ do not differ significantly by DMRT at 0.05 level.

\section{Plant Height}

The plant height measured at maturity stage showed a non-significant difference among the genotypes in both location and their interaction. However, location showed a highly significant effect on height of the plant. Except genotype AVON-1052, all other genotypes had more plant height in HRS, Dailekh than HRD, Khumaltar. It could be due to high growing temperature in HRS, Dailekh than Khumaltar. The detail data on plant height in each location and their combined effect is presented in Table 2. 
Table 2. Effect of onion genotypes on plant height in mid hills of Nepal, 2017/18

\begin{tabular}{|c|c|c|c|}
\hline \multirow[t]{2}{*}{ Genotype } & \multicolumn{3}{|c|}{ Plant height $(\mathrm{cm})$} \\
\hline & Dailekh & Khumaltar & Mean \\
\hline AVON-1016 & 47.60 & 35.41 & 41.49 \\
\hline AVON-1027 & 50.30 & 38.40 & 44.37 \\
\hline AVON-1028 & 48.10 & 39.10 & 43.61 \\
\hline AVON-1052 & 38.50 & 39.89 & 39.21 \\
\hline AVON-1103 & 44.30 & 37.98 & 41.12 \\
\hline Red Creole & 49.70 & 39.25 & 44.48 \\
\hline Mean & 46.51 & 38.34 & 42.38 \\
\hline \multicolumn{4}{|l|}{ F-test } \\
\hline Genotypes & NS & NS & NS \\
\hline Locations & - & - & $* * *$ \\
\hline Geno. $\times$ Loc. & - & - & NS \\
\hline LSD (0.05) & - & - & \\
\hline Genotypes & - & - & - \\
\hline Locations & & - & 2.836 \\
\hline Geno. $\times$ Loc. & & - & \\
\hline $\mathrm{CV} \%$ & 9.5 & 10.5 & 9.7 \\
\hline
\end{tabular}

NS = Non Significant; , *** Significant at $<0.001$ levels respectively.

Neck and Bullb Diameter

The genotypes showed a significant difference on neck diameter at HRS, Dailekh and interaction of genotype with HRS, Khumaltar location. The lowest neck diameter $(10.93 \mathrm{~mm})$ was recorded on genotype ANOVA-1052 followed by genotypes ANOVA-1028 (11.37 mm), ANOVA-1027 (12.20 $\mathrm{mm})$ and ANOVA-1016 $(13.10 \mathrm{~mm})$ whereas, the highest neck diameter $(17.17 \mathrm{~mm})$ on Red Creole. The combined data showed significant effect of genotypes, location and genotype and locations interaction on neck diameter of genotypes. The recommended variety Red Creole had the thickest $(17.08 \mathrm{~mm})$ neck diameter and it was statistically at par with genotype AVON-1103 $(14.59 \mathrm{~mm})$. The thinnest neck diameter $(12.59 \mathrm{~mm})$ was observed in genotype AVON-1052 and it was statistically at par with other genotypes except Red Creole (Table 3). The mean neck diameter (13.41 mm) was recorded significantly thinner in HRS, Dailekh than HRD, Khumaltar $(15.10 \mathrm{~mm})$. The thick neck diameter in HRS, Khumaltar could be due to cool and wet climate and 11 days early harvesting than HRS, Dailekh. The genotypes showed non-significant effect on bulb diameter on both locations . However, the interaction effect of locations and genotypes showed highly significant effect on bulb diameter. All genotypes showed higher bulb diameter in HRS, Dailekh than HRD, Khumaltar.

Table 3. Effect of onion genotypes on neck and bulb diameter in mid hills of Nepal, 2017/18

\begin{tabular}{|c|c|c|c|c|c|c|}
\hline \multirow[t]{2}{*}{ Genotype } & \multicolumn{3}{|c|}{ Neck diameter (mm) } & \multicolumn{3}{|c|}{ Bulb Diameter $(\mathrm{cm})$} \\
\hline & Dailekh & Khumaltar & Mean & Dailekh & Khumaltar & Mean \\
\hline AVON-1016 & $13.10 b c$ & 14.17 & $13.63 \mathrm{~b}$ & 74.10 & 60.40 & 67.23 \\
\hline AVON-1027 & $12.20 c$ & 15.88 & $14.04 \mathrm{~b}$ & 80.30 & 66.70 & 73.54 \\
\hline AVON-1028 & $11.37 c$ & 15.17 & $13.27 \mathrm{~b}$ & 72.30 & 66.00 & 69.15 \\
\hline AVON-1052 & $10.93 c$ & 14.25 & $12.59 \mathrm{~b}$ & 72.00 & 71.80 & 71.40 \\
\hline AVON-1103 & $15.70 a b$ & 14.12 & $14.59 \mathrm{ab}$ & 71.80 & 63.80 & 67.83 \\
\hline Red Creole & $17.17 a$ & 17.0 & $17.08 \mathrm{a}$ & 77.80 & 59.20 & 68.48 \\
\hline Mean & 13.41 & 15.10 & 14.20 & 74.71 & 64.70 & 69.69 \\
\hline \multicolumn{7}{|l|}{ F-test } \\
\hline Genotypes & $* * *$ & NS & $* * *$ & NS & NS & NS \\
\hline Locations & - & - & $* * *$ & - & & $* * *$ \\
\hline Geno. $\times$ Loc. & - & - & $* * *$ & - & - & $*$ \\
\hline \multicolumn{7}{|l|}{ LSD (0.05) } \\
\hline Genotype & 2.266 & - & 1.796 & - & - & - \\
\hline Location & - & - & 1.035 & - & - & 3.238 \\
\hline Geno. $\times$ Loc. & - & - & 2.535 & - & - & 7.931 \\
\hline $\mathrm{CV} \%$ & 9.4 & 9.8 & 10.5 & 5.9 & 7.3 & 6.7 \\
\hline
\end{tabular}

NS = Non Significant;,$*$ and *** Significant at 0.05 and $<0.001$ levels respectively. In column figures with same small letter (s) do not differ significantly by DMRT at 0.05 level. 
Weight and Yield of Bullbs

The genotypes showed the significant differences on individual mean bulb weight in both HRS, Dailekh and HRD, Khumaltar and their interaction over locations (Table 4). In HRS, Dailekh the genotype AVON-1027 produced significantly high bulb weight (151.1 g) whereas other genotypes produced statistically same yield. In HRD, Khumaltar, the genotype AVON-1028 produced the maximum bulb weight (142.6 g) and it was statistically at par with genotype AVON-1052 (138.6 g) and AVON-1027 (135.0 g). The minimum bulb weight (73.6 g) was recorded in genotype AVON1016 and it was at par with red Creole (82.8 g) and AVON -1103 (86.0 g). Among the location, HRS, Dailekh produced statistically higher bulb weight than HRD, Khumaltar. The interaction effect of gentypes and locations also showed highly significant differences on individual bulb weight. The maximum bulb weight (180.3 g) was recorded on genotype AVON-1027 and the minimum (117.0 g) on AVON-1103. It is already known that the mid western region is suitable for production of onion since many yerars due to high sunshine and no foggy weather during vegetative growing period and dry weather and no rain at maturity period which favour the high photosynthetic rate and higher yield, while in Kathmandu there is foggy weather and less sunshine during vegetative growing period and early rain during crop maturity period which may affect the yield of onion crops.

The genotypes also showed the significant differences on adjusted bulb yield per hectare both in HRS, Dailekh and HRD, Khumaltar (Table 4). In HRS, Dailekh the genotype AVON-1027 produced the highest bulb yield $(41.07 \mathrm{t} / \mathrm{ha})$ and the lowest yield $(25.27 \mathrm{t} / \mathrm{ha})$ was produced by the genotype AVON-1103. Similary in HRD, Khumaltar the highest yield (36.80 t/ha) was observed on genotype AVON-1052 and it was at par with genotype AVON-1027 (36.60 t/ha), AVON-1028 (33.70 t/ha) and the lowest yield (20.70 t/ha) was found in Red Creole and it was statistically at par with genotype AVON-1103 (21.50 t/ha). The pooled analysis of bulb yield over locations showed that genotype AVON-1027 produced the highest bulb yield ( $38.83 \mathrm{t} / \mathrm{ha}$ ) and the genotype AVON-1103 produced the lowest yield (23.39 t/ha). The yield of each genotype is presented in Table 4.

Table 4. Effect of onion genotypes on individual bulb weight and bulb yield in mid hills of Nepal, 2017/18

\begin{tabular}{|c|c|c|c|c|c|c|}
\hline \multirow[t]{2}{*}{ Genotype } & \multicolumn{3}{|c|}{ Weight of individual bulb (g) } & \multicolumn{3}{|c|}{ Yield (t/ha) } \\
\hline & Dailekh & Khumaltar & Mean & Dailekh & Khumaltar & Mean \\
\hline AVON-1016 & $173.2 b$ & $73.6 b$ & $123.4 b$ & $32.07 b c$ & $28.10 a b$ & $30.07 b$ \\
\hline AVON-1027 & $225.5 a$ & $135.0 a$ & $180.3 a$ & $41.07 a$ & $36.60 a$ & $38.83 a$ \\
\hline AVON-1028 & $151.1 b$ & $142.6 a$ & $146.8 a b$ & $29.23 \mathrm{bcd}$ & $33.70 a$ & $31.48 a b$ \\
\hline AVON-1052 & $156.7 b$ & $138.6 a$ & $147.7 a b$ & $27.13 c d$ & $36.80 a$ & $31.97 a b$ \\
\hline AVON-1103 & $148.0 \mathrm{~b}$ & $86.0 \mathrm{~b}$ & $117.0 \mathrm{~b}$ & $25.27 d$ & $21.50 \mathrm{~b}$ & $23.39 b$ \\
\hline Red Creole & $183.5 b$ & $82.8 b$ & $133.2 b$ & $34.10 b$ & $20.70 \mathrm{~b}$ & $27.40 \mathrm{~b}$ \\
\hline Mean & 173.0 & 109.8 & 141.4 & 31.47 & 29.60 & 30.52 \\
\hline \multicolumn{7}{|l|}{ F-test } \\
\hline Genotypes & $* *$ & $* * *$ & $* * *$ & $* * *$ & $* * *$ & $* * *$ \\
\hline Location & - & - & $* * *$ & - & - & - \\
\hline Geno. $\times$ Loc. & - & - & $* * *$ & - & - & $* * *$ \\
\hline \multicolumn{7}{|l|}{ LSD $(0.05)$} \\
\hline Genotype & 38.63 & 39.20 & 26.59 & 5.933 & 9.30 & 5.527 \\
\hline Locations & - & - & 15.35 & & & - \\
\hline Geno. $\times$ Loc. & - & - & 37.60 & - & & 7.817 \\
\hline $\mathrm{CV} \%$ & 12.3 & 19.6 & 15.7 & 10.4 & 17.3 & 15.1 \\
\hline
\end{tabular}

(s) do not differ significantly by DMRT at 0.05 level.

Quality Parameters

Foliage and Bulb

The quality parameters were recorded on ten randomly selected plants and bulbs as per international protocols (http://bit.ly/2sKsGSi) in different parameters. The genotypes AVON 1016, AVON 1028, AVON 1103 showed green foliage, AVON 1028, AVON 1052 and Red Creole showed dark green foliage (Table 5). Degree of waxiness of foliage was recorded strong in genotypes AVON 1028 and AVON 1052; medium in AVON 1016, AVON 1103 and Red Creole and weak in AVON 1027. Foliage cracking at maturity was observed medium in three genotypes (AVON 1016, AVON 1027 
and Red Creole); and strong in other three genotypes (Table 5). All of the tested genotypes produced flat globe shaped bulb. The varieties Red Creole and AVON 1016 produced highly variable and variable bulb uniformity while other imported genotypes produced uniform bulbs.

Table 5. Foliage and bulb parameters of onion genotypes in Khumaltar Nepal, 2017/18

\begin{tabular}{lccclc}
\hline Genotype & Foliage color & $\begin{array}{c}\text { Degree of } \\
\text { Waxiness }\end{array}$ & $\begin{array}{c}\text { Foliage } \\
\text { Cracking }\end{array}$ & Bulb Shape & Bulb Uniformity \\
\hline AVON 1016 & Green & Medium & Medium & Flat Globe & Variable \\
\hline AVON1027 & Green & Weak & Medium & Flat Globe & Uniform \\
\hline AVON1028 & Dark Green & Strong & Strong & Flat Globe & Uniform \\
\hline AVON1052 & Dark Green & Strong & Strong & Flat Globe & Uniform \\
\hline AVON1103 & Green & Medium & Strong & Flat Globe & Uniform \\
\hline Red Creole & Dark Green & Medium & Medium & Flat Globe & Variable \\
\hline
\end{tabular}

Colour of Bulbs, Skin and Flesh

The genotypes showed the differences on bulb colour. Three genotypes namely, AVON 1016, AVON 1103 and Red Creole produced the red bulb color and AVON 1027, AVON 1028 and AVON 1052 had yellowish bulb color. The skin colour was dark violet in AVON 1016; violet in genotype AVON1103 and Red Creole and light yellowish brown in AVON 1027 and AVON 1028 and greenish white in AVON 1052. The genotypes AVON 1016, AVON 1103 and Red Creole had violet/white colour and other genotypes had cream colour (Table 6). In comparison with white onion, red onions are preferred by Nepalese consumers.

Table 6. Colour and pungency of onion genotypes in mid hills of Nepal, 2017/18

\begin{tabular}{lccc}
\hline Genotype & Bulb colour & Bulb skin colour & Flesh colour \\
\hline AVON 1016 & Red & Dark violet & Violet/White \\
\hline AVON 1027 & Yellowish & Light yellow / brown & Cream \\
\hline AVON 1028 & Yellowish & Light yellow /brown & Cream \\
\hline AVON 1052 & Yellowish & Greenish/ white & Cream \\
\hline AVON 1103 & Red & Violet & Violet/White \\
\hline Red Creole & Red & Violet & Violet/White \\
\hline
\end{tabular}

Bulb Thickness, Number of Scale, Hearting, and Pungency

These parameters were recorded in HRD, Khumaltar after harvesting the bulbs. The bulb thickness (polar diameter) and bulbs hearting showed highly significant differences among the genotypes. Bulbs thickness was observed the maximum $(55.73 \mathrm{~mm})$ in genotype AVON-1027 and it was statistically at par with genotype AVON-1016 $(55.28 \mathrm{~mm})$. The minimum thickness of bulbs ( 43.93 $\mathrm{mm})$ was recorded in check variety Red Creole followed by AVON-1103 (45.18 mm) and AVON1052 (47.94 mm). Based on organeleptic taste high pungency was observed in Red Creole and low pungency in AVON-1016 and AVON-1027, wheras, other genotypes showed medium pungency level (Table 7). Similar result on pungency was reported by AVRDC team in 2018 (http://bit.ly/2MyepBg

Table 7. Evaluation of yield parameter of different onion genotypes at HRD, Khumaltar, 2017/18

\begin{tabular}{|c|c|c|c|c|}
\hline Genotype & $\begin{array}{c}\text { Bulb thickness } \\
\text { (mm) }\end{array}$ & No of scales & Bulb hearting + & Pungency \\
\hline AVON 1016 & $55.28 a$ & 8.0 & $2.60 c$ & Low \\
\hline AVON 1027 & $55.73 a$ & 8.33 & $1.90 c$ & Low \\
\hline AVON 1028 & $48.73 b$ & 7.33 & $2.39 c$ & Medium \\
\hline AVON 1052 & $47.94 b c$ & 7.0 & $2.32 c$ & Medium \\
\hline AVON 1103 & $45.18 b c$ & 7.33 & $1.93 c$ & Medium \\
\hline Red Creole & $43.93 b c$ & 7.67 & $3.63 b$ & High \\
\hline F-test & $* * *$ & NS & $* * *$ & \\
\hline LSD & 5.41 & 1.109 & 0.854 & \\
\hline CV (\%) & 6.3 & 8.2 & 16.6 & \\
\hline
\end{tabular}


Besides, yield and quality parameters, bulbs of all the tested genotypes were stored both in HRD, Khumaltar and HRS, Dailekh to study the postharvest shelf-life of bulb and study on seed production in the following season.

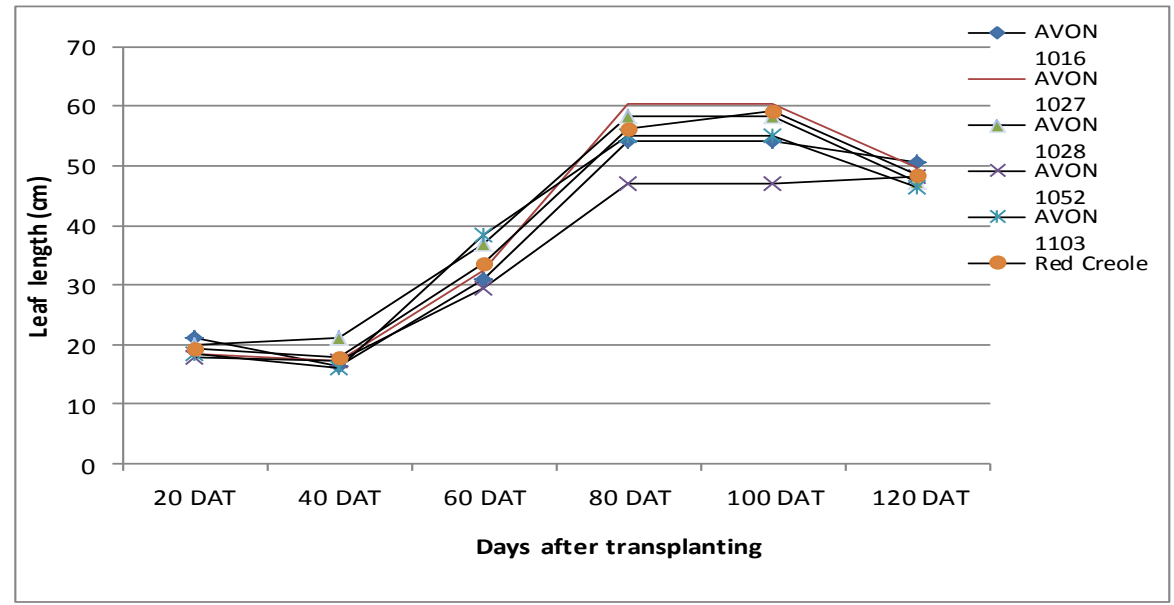

Figure 1. Leaf length of different onion genotypes at different days after transplanting

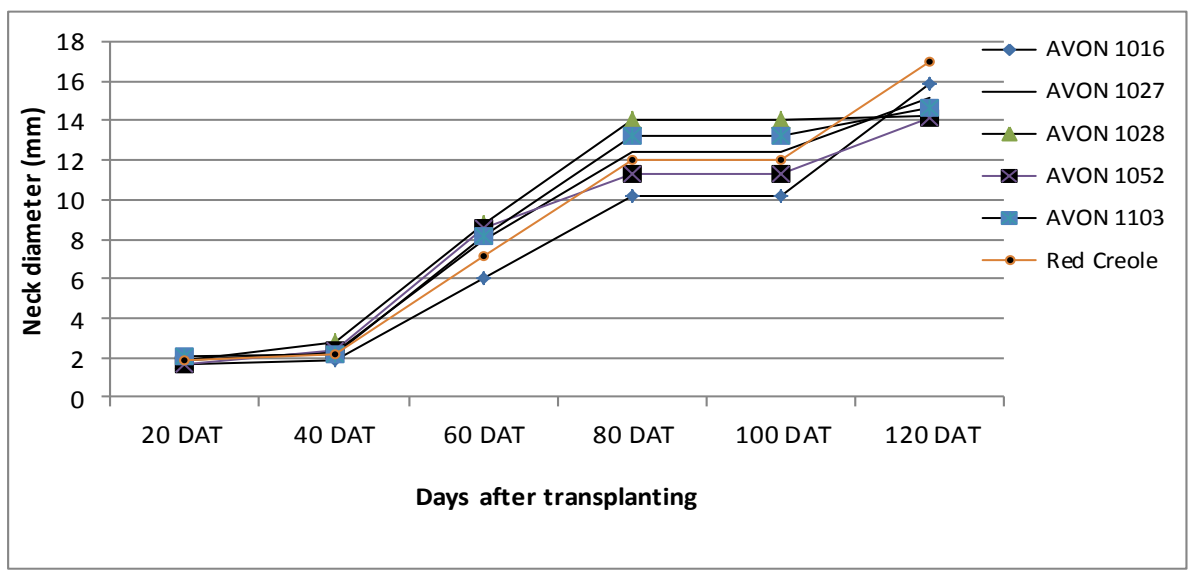

Figure 2. Neck diameter different onion genotypes at different days after transplanting
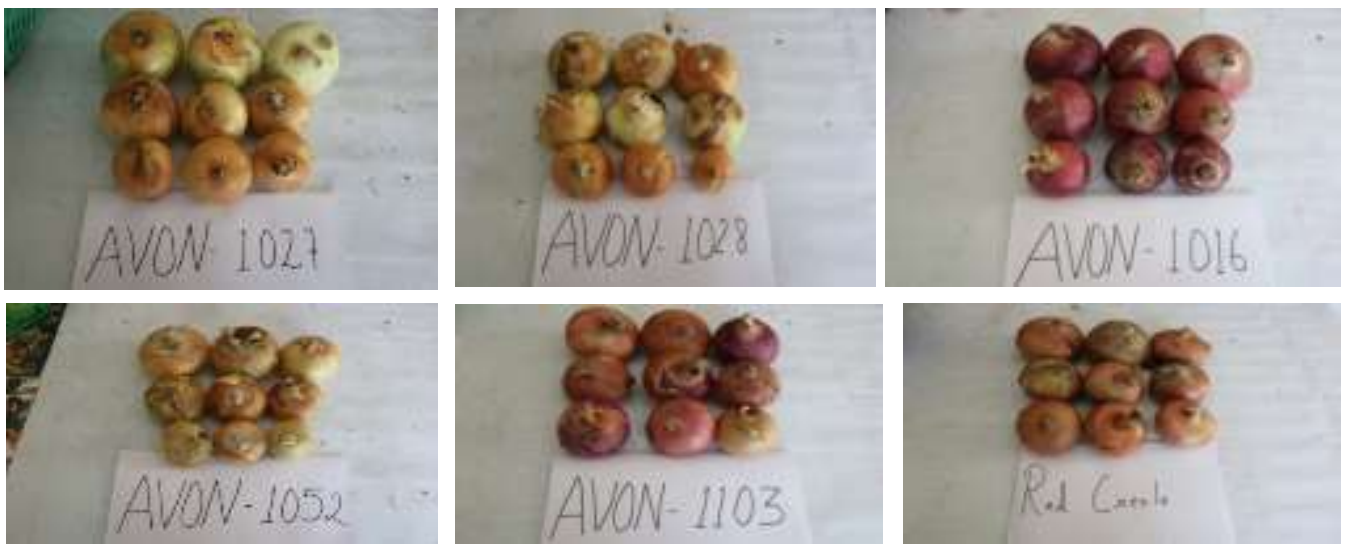

Figure 3. Bulb morphology of onion genotypes tested at HRS, Dailekh, 2017/18.

\section{DISCUSSION}

The genotypes showed the highly significant differences on number of leaf per plant at HRD, Khumaltar and over locations. The higher number of leaves in HRD, Khumaltar than HRS, Dailekh could be due to mild climate and wet condition in HRD,Khumaltar than HRS, Dailekh. Howevers, more plant height in HRS, Dailekh than HRD, Khumaltar could be due to high growing temperature in HRS, Dailekh . In Dailekh the production area is open with early sun rise and clear weather while 
in Khumaltar is valley and surrounded by hills from all sides which results foggy weather and late sun rise and effect on photosynthesis rate and time. It also have effect on thicker neck diameter in HRD, Khumaltar. In HRS, Dailekha, all genotypes showed more diameter of bulbs (Table 3) contrary to thinner neck, it could be due to higher rate of sunshine and frost free during morning duration which favour the growth of bulbs.

Among two locations, HRS, Dailekh produced statistically higher bulb weight than HRD, Khumaltar due to favourable environment rather than genotypic effect. It is already known that the mid western region is suitable for production of onion since many yerars due to high Sunshine and no foggy weather during vegetative growing period and dry weather and no rain at maturity period which favour the high photosynthetic rate and higher yield. So Nepalese government has already established onion seed production farm in this regions.

The varieties Red Creole and AVON 1016 produced highly variable and variable bulb uniformity while other imported genotypes produced uniform bulbs. The variable and highly variable bulbs size could be due to lack of purity of seeds.

The variety evaluation works in the past showed that Red Creole wasfound superior than other varieties and the majority of area is coved by thais variety. Sharma and Neupane (1995) conducted onion varietal trials in IAAS, Rampur, Chitwan and reported that Red Creole was found superior in term of yield than other two varieties (Kathmandu Local, and Nasik Red ) on October and November planting. They also reported that the open pollinated varieties XP 8403, Tropical Gold and Agri Found Red produced higher yield $(17.2,16.0$ and 14.6 t/ha) than popular cultivar Red Creole. However, in this study the introduced genotypes AVON 1027 (38.83 t/ha), AVON 1052 (31.97 t/ha) and AVON 1028 (31.48 t/ha) produced significantly higher yield than recommended and commercially cultivated check variety Red Creole (27.04 t/ha). The lowest mean marketable yiel $(23.39 \mathrm{t} / \mathrm{ha})$ was obtained from genotype AVON-1103. The variation observed among different parameters of genotypes might be due to capacity to perform in different agro-climatic conditions and their genetic makeup. Simon et al (2014) reported the highest and lowest bulb yield (15.94 t/ha and $9.17 \mathrm{t} / \mathrm{ha}$ ) from variety Nafis and Adama Red respectively. Yield differences on different onion varieties due to interaction of genetic and environmental conditions was reported by Simon et.al., 2014. Quality parameters like skin colour, pungency, number of scale and bulb hearting (Table 6 and 7) are major criteria for adaptation of genotype by farmers. Some of tested genotypes in this study have showed good scoring in these traits and found promising for adoption in Nepalese conditions.

\section{CONCLUSION}

The introduced onion genotypes AVON 1027, AVON 1028 and AVON 1052 were found promising for bigger bulb weight and higher yield than recommended and mostly cultivated variety Red Creole in mid hills of Nepal. However, new genotypes need to be verified in coming years for their postharvest shelf-life, seed production potential and farmers acceptanc test so as to make cultivation recommendation.

\section{ACKNOWLEDGMENTS}

The authors gratefully acknowledged the Nepal Seed and Fertilizer Project (NSFP), Lalitpur, Nepal for financial support and importing onion seeds from Asian Vegetable Research and Development Centre (AVRDC), Taiwan for this study.

\section{REFERENCES}

Chalise B and TB Pun. 2014/2015. Nepalma Kheki Garine Mukhya Tarkari Baliharuko Biu Utpadhan Prabidhi (Nepali Version). Nepal Agricultural Research Council, Horticulture Research Station, Kimuganu, Dailekh.

Descriptors for Allium. http://archive-ecpgr.cgiar.org/fileadmin/bioversity/publications/pdfs/728_ _Allium_spp._cache=1415188979.pdf

IHD. 2014. Indian Horticulture Database, 2014. National Horticulture Board. Ministry of Agriculture, Government of India. http://www.nhb.gov.in 
NFTS. 2016/17. Nepal Foreign Trade Statistics, Fiscal Year 2016/17. Government of Nepal, Ministry of Finance, Department of Customs, Tripureshwor, Kathmandu; p.730

NOA. 2018. The National Onion Association, USA. http: www.onion-usa.org/all-about-onions/consumption

Sharma , MD. and KR. Neupane. 1995. Performance of onion cultivars in Inner Terai of Nepal. J. Inst.Agric.Animal. Sci. Volume 16, 1995.

Simon T, Tora M, Shumbulo A and Urkato S . 2014. The effect of variety, Nitrogen and Phosphorus fertilization on growth and bulb yield of onion (Allium Cepa L.) at Wolaita, Southern Ethiopia. Journal of Biology Agriculture and Healthcare 4:89-96.

VDD. 2073/74. Annual Progress report of Potato, Vegetables and Spices Development Program Published by Vegetable Development Directorate, Khumaltar Nepal.

WVC. 2018. Table of Characteristics of AVRDC developed onion lines. http//avrdc/wpfb-file/tablecharacteristics-of avrdc-developed onion-line-pdf2.

||------|||-------|| 